\title{
Participation of women in management positions in an institution of higher education of public management - Ciudad Del Este - Paraguay
}

DOI: $10.46932 / \mathrm{sfjdv2n1-013}$

Received in: November 1st, 2020

Accepted in: December 30th, 2020

\author{
Karen Natali Backes Dos Santos \\ Graduate School of the National University of the East, Ciudad del Este, Paraguay. \\ María Victoria Zavala Saucedo \\ Graduate School of the National University of the East, Ciudad del Este, Paraguay.
}

\begin{abstract}
the objective of this study is to determine the rate of female participation in management positions in a public management university in Paraguay. responds to a documentary design developed through three categories of analysis: shared power, individual power, and access possibilities. The data were collected from institutional documents available on the web and provided by the institution. The Atlas.ti software and electronic spreadsheets were used for data processing. The results reveal a greater male presence either in positions of individual power and shared power, which leads to a low probability of access by women to those positions in the short and medium term. In conclusion, the power is inversely proportional to the presence of women, the greater the power granted by the position, the lower the representation of women; the permanence of cultural models that guide the male at the highest hierarchical level; the monopolization of positions and decisions in favor of men.
\end{abstract}

Keywords: Gender, Higher Education, power, female participation, equity.

\section{INTRODUCTION}

The division of labor according to traditional roles, based on culture, assigns the role of provider to the man and the role of caregiver to the woman, which generates on the one hand "overvaluation of productive work and on the other hand, a devaluation of reproductive work" (SERAFINI GEOGHEGAN, 2018, p. 3)

However, according to Serafini Geoghegan (2018), women contribute to family income to improve the quality of life and reduce poverty, in addition to the domestic activities that women do with no remuneration, are essential for well-being and survival.

The entry of women into the labor market is developed with no revocation to the domestic sphere, which, on one hand generates an role overload, translates into occupational segregation, precarious job and as job offers constraints that in the long term constrains women's economic opportunities. On the 
other hand, women's work opportunities are limited by the time and the need for a balance between family and work (CUADRADO; MORALES, 2007; MORELO ALONSO; CUADRADO GUIRADO; GARCÍA AEL; RECIO SABOYA; RUEDA LAFFONT, 2009; SERAFINI GEOGHEGAN, 2018).

Access to leadership positions differ for men and women, that is, in most Western societies, presence of women in managerial areas exist less regardless of either the type of organization or the training level and competence of women (SQUARE; MOLERO; NAVAS, 2003).

This difference in favor of men, can be explained through different theories that speak about access to social networks of the company, the role overload (MORELO ALONSO, 2009), the presence of invisible hurdles that can influence access by women to managerial positions such as: the Crystal Ceiling (WIRTH; 2001) and the Crystal Labyrinth (EAGLY AND CARLI; 2007); theories that talk about the existence of invisible but effective backstops that allow women to advance only to a certain level in the hierarchical scale of organizations.

The glass ceiling is defined as invisible barriers of cultural origin that impede the promotion of women to high management positions, this concept indicates the limit which the women can rise to in an organization (WIRTH; 2001).

Eagly and Carli (2007) explain the current situation of women in the higher hierarchical positions through the metaphor of the glass labyrinth, which shows that women are not forbidden from accessing high positions but, compared to the men they must overcome a large number of hindrances that require more dedication, effort and time to reach.

Regarding the strategies that seek equity, the IV National Equality Plan 2018 - 2024 (IV PlaNI) is in force in Paraguay, which the main objective is to promote real and effective equality by mitigating the obstacles that impede the full development of women. Among the specific objectives of this plan, the one that refers to the mechanisms that allow access under equal conditions and the permanence of women in high-ranking positions in different power levels of the State stands out. Likewise, this plan proposes to generate conditions of economic autonomy based on a family-work balance and access to the labor market in equitable and non-stereotyped conditions (MINISTRY OF WOMEN, PARAGUAY, 2018).

A study made on the participation of women in the government organisms of the National University of Asunción reveals that the presence of women is reduced and a vertical discrimination in higher hierarchies positions exists. The greatest female presence is placed in the student councilor estament, with no parity, while the male presence is considerably superior in positions with greater power (CONTRERA GONZÁLEZ, 2018).

In the line of thought about the commitment of the organization has with the female leadership, the selected university in this study for its code of ethics, establishes equity as institutional values in order 
to enable equality, access to work according to the types and the available opportunities to education, information and knowledge.

Also, since 2015 the studied university integrates a network conformed by 23 Higher Education Institutions (HEIs) from 18 Latin American countries and 4 European countries, whose purpose is developing strategic measures to promote gender equality and the participation of women in leadership positions at the academy, as well as research and society in general (INSTITUTO TECNOLÓGICO DE COSTA RICA, 2015).

This network was created based on a project called Equality "Strengthening Women Leadership in Latin American HEIs and the Society", implemented with the financial support of the ALFA III Program of the European Commission, in order to implement a series of specific measures such as studies, capacity building, sensitization programs and political support actions during the 3 -year term of the project lasting, between 2012 and 2015.

Participation in the aforementioned project demonstrated the institutional difficulty in accessing data related to women participation in the university environment, hence, establishing the participation rate for women in managerial positions was the motivation for undertaking this study.

Therefore, the general objective of the research was to determine the rate of female participation in management positions at the selected university.

In this manner, the specific objectives sought:

- To identify the participation of women in positions of shared power in a University of Paraguay.

- Determine the participation of women in positions of individual power in a University of Paraguay.

- Estimate the probability of access of the academics to the position of Dean and Rector of the university under study.

\section{MATERIALS AND METHODS}

The study design is documentary, the data were obtained by analyzing sources such as: regulations, statutes, reports, minutes of meetings and documents published on the web pages of the university's Schools and data provided by the institution about the number of scholars according to the ranges established in the regulations.

Shared power was used as a category of analysis; individual power and the possibility of access to the power. 
In the category of shared power, the integration of: the University Assembly, the Higher University Council, Directive Council as well as the positions of tenured Professor, Adjunct Professor and Assistant Professor were analyzed.

Regarding individual power, the positions of rector, vice-rector, dean, vice-dean and management positions.

Based on the established categories and the selected sources, the data was codified and systematized through the ATLAS.ti analysis program.

\section{RESULTS AND DISCUSSION}

The analyzed institution has spaces of power defined in the statute; positions of shared and individual power can be identified. Among the first are: University Assembly, Higher University Council, Directive Council; Tenured Professor, Adjunct Professor and Assistant Professor; although these last positions correspond to the academic sector, in this research they were included in the shared power because they are the ones that can run for, vote and thereby define institutional representation.

In the positions of individual power are: Rector, Vice-Rector, Deans, Vice-deans and directors of the different areas.

In this case, the University Assembly is the highest deliberative body of the institution's government, it is conformed by the current members in exercise of the Higher University Council, two teaching members in exercise of the Directive Council of each faculty; the non-teaching member in exercise of the Directive Council of each faculty; a student member in exercise of the Directive Council of each faculty.

The University Assembly of the institution under study is formed by 42 people where 13 are women and 29 are men (there is one woman for every $2.23 \mathrm{men}$ ); In relation to the data obtained in 2017 , the gender gap has decreased by 1.43 points.

In relation to the Higher University Council, the body that exercises the government of the university in accordance with the university policy defined by the Assembly, it is comprised of the Rector, Vice-Rector, a teacher for each faculty, a non-teaching graduate and three students. According to the data currently obtained, the Higher University Council is made up of 18 people (5 women and 13 men), that is, there is one woman for every $2.6 \mathrm{men}$; in this way, the gap has been reduced by 0.9 point compared to the one existing in 2017.

Next in the hierarchical scale of power in the institution, are the members of the Directive Council of each faculty, which is composed of the dean, the vice-dean, five professors in exercise of the chair, a non-teaching graduate and two students. 
Table 1. Directive Council of each school discriminated by sex

\begin{tabular}{lll}
\hline Academic Unit & Women & Men \\
\hline School of Economics & 6 & 4 \\
School of Philosophy & 3 & 7 \\
School of Law and Social Sciences & 3 & 7 \\
School of Agronomic Engineering & 0 & 10 \\
School of Health Science & 6 & 4 \\
Polytechnic Faculty & 1 & 9 \\
\hline Total Source: Institutional website 2020. & $\mathbf{4 1}$
\end{tabular}

Source: Institutional website, 2020.

As can be seen in the table, the Directive Council of the schools integrated by a total of 60 members, which 19 are women and 41 are men (there is a woman for each 2.1 men), these data indicate that the gap of gender has decreased 0.42 points in relation to the data of the year 2017 .

The statute establishes that the election of the educational counselors, shall be made in elections of tenured professors, adjuncts and assistants; in this act, five teaching counselors will be elected, in which four of them must have the category of tenured or adjunct professor.

According to the obtained data in the tenured professor category, women are at a disadvantage because of the 385 positions, only 120 are held by women and 265 by men (it indicates that there is one woman for every 2.2 men); These results show the decrease of the gender gap by 0.8 point in relation to the data for the year 2017. Regarding the category assistant professor, the institution has 413 professors in this range, where 197 are women and 216 are men (for every 1.09 men there is a woman), which represents a reduction in the gender gap by 0.2 compared to 2017 .

For its part, the adjunct professor category is occupied by 161 professors, among whom 75 are women and 86 are men (there is one woman for every 1.14 man), the gender gap has decreased by 0.82 points in relation to the year 2017.

At the same time, the institution has 518 teachers in the assistant professor category, of which 226 are women and 292 are men (there is one woman for every 1.29 men), this category has not changed in relation to 2017.

Table 2. Gender gap in positions of shared power

\begin{tabular}{llll}
\hline Shared power & $\begin{array}{l}\mathbf{2 0 2 0} \\
\text { Women }\end{array}$ & Men & $\begin{array}{l}\text { Male for each } \\
\text { female }\end{array}$ \\
\hline University Asembly & 13 & 29 & 2,2 \\
Higher University Council & 5 & 13 & 2,6 \\
Directive Council & 19 & 41 & 2,2 \\
Tenured Professor & 120 & 265 & 2,2 \\
Adjunct Proffesor & 75 & 86 & 1,1 \\
Assistant Teacher & 226 & 292 & 1,3 \\
\hline Total & $\mathbf{4 5 8}$ & $\mathbf{7 2 6}$ & $\mathbf{1 , 6}$ \\
\hline
\end{tabular}

Source: Institutional website and data provided by university, year 2020. 
It can be seen in the data that female participation is inversely proportional to the power granted by the positions; namely, the more power a position grants, the lower the degree of women participating, hence, the lower the degree of power in a position, the greater the female participation.

Nowadays, the gender gap in positions of shared power is 1.6.

Regarding the position of Rector and Vice-Rector, it is important to mention that in 27 years since the foundation of the university there has been no female presence in these positions, namely, they have been held by a male until this date.

Discriminating data, the segregation between men and women who occupy the dean position of the different colleges of the university studied can be seen.

Table 2. Distribution of positions of power in academic units.

\begin{tabular}{lll}
\hline Academic Units & Women & Men \\
\hline Deans & 1 & 5 \\
Vice-Dean & 0 & 6 \\
Managerial positions & 18 & 31 \\
\hline Total & $\mathbf{1 9}$ & $\mathbf{4 2}$ \\
\hline
\end{tabular}

Source: Institutional website and data provided by the university, year 2020 .

Table 4. Distribution of positions of power in the Rectorate

\begin{tabular}{lll}
\hline Rectorate & Womenr & Men \\
\hline Rector & 0 & 1 \\
Vice-rector & 0 & 1 \\
Directors & 5 & 12 \\
\hline Total & $\mathbf{5}$ & $\mathbf{1 4}$ \\
\hline \multicolumn{1}{c}{ Source: Institutional website and data provided by the university, year 2020. }
\end{tabular}

To sum up of the total of 6 deans, 5 are held by men and only 1 is held by a woman. In relation to the vice deans, it is observed that this position is entirely held by men. In these two categories, the gender gap has not changed.

Finally, at the university level there are a total of 78 managerial positions (Schools and rectorate), of which 56 are held by men and 22 by women (there is one woman for every 2.54 men), which indicates that the gap has increased in 0.2 points compared to 2017.

Table 5. Gender gap in positions of individual power

\begin{tabular}{llll}
\hline Individual power & $\mathbf{2 0 2 0}$ & & $\begin{array}{l}\text { Man } \\
\text { every } \\
\text { Woman }\end{array}$ \\
\hline Rector & Women & Men & 1,0 \\
Vice-rector & 0 & 1 & 1,0 \\
Deans & 0 & 1 & 5,0 \\
Vice-deans & 1 & 5 & 1,0 \\
Directors & 0 & 1 & 2,5 \\
\hline Total & 22 & 56 & $\mathbf{2 , 8}$ \\
\hline
\end{tabular}

Source: Institutional website and data provided by university, year 2020. 
The table shows that the gender gap in terms of individual power is 2.8 , which may significantly constraint women's access to positions of individual and shared power in the next years.

The following visual resources detail the comparative data on the occupation of positions by sex in the years 2017 and 2020, which indicate a reduction in the gender gap of 0.2 in relation to the year 2017.

It is highlighted that, although the number of women has increased, there is still a significant difference in favor of the male population.

Table 6. Comparison between the year 2017 and 2020

\begin{tabular}{lllll}
\hline $\begin{array}{l}\text { Shared and individual } \\
\text { power }\end{array}$ & $\begin{array}{l}\mathbf{2 0 1 7} \\
\text { Women }\end{array}$ & Men & $\begin{array}{l}\mathbf{2 0 2 0} \\
\text { Women }\end{array}$ & Men \\
\hline University Assembly & 9 & 33 & 13 & 29 \\
Higher University Council & 4 & 14 & 5 & 13 \\
Directive Council & 17 & 43 & 19 & 41 \\
Tenured Professor & 56 & 166 & 120 & 265 \\
Adjunct Professor & 50 & 98 & 75 & 86 \\
Assistant teacher & 226 & 292 & 226 & 292 \\
Rector & 0 & 1 & 0 & 1 \\
Vice-rector & 0 & 1 & 0 & 1 \\
Deans & 1 & 5 & 1 & 5 \\
Vicedeans & 0 & 6 & 0 & 1 \\
Directors & 21 & 46 & 22 & 56 \\
\hline Total & $\mathbf{3 8 4}$ & $\mathbf{7 0 5}$ & $\mathbf{4 8 1}$ & $\mathbf{7 9 0}$ \\
\hline
\end{tabular}

Figure 1. Comparison of the gender gap between 2017 and 2020.

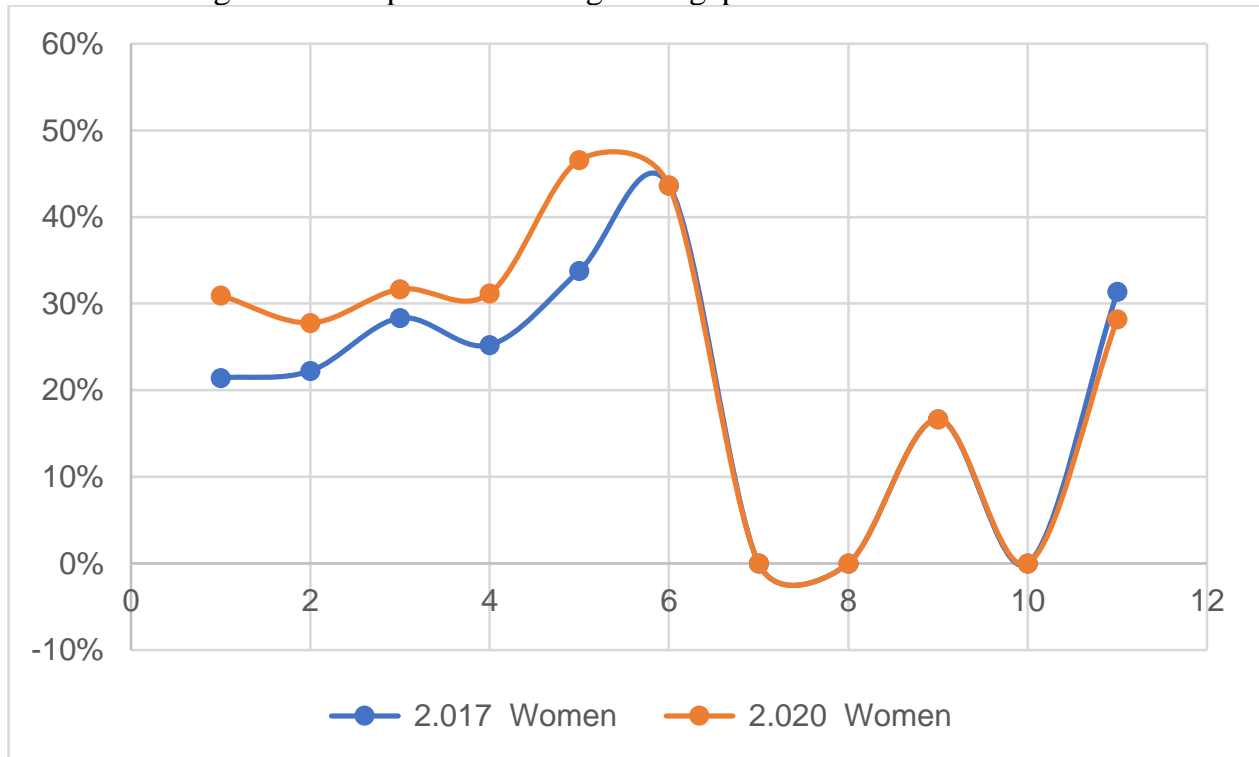

Source: Own elaboration based on analyzed data, 2020.

The results regarding the gender gap in individual power guide the analysis of the possibility of a woman reaches the position of greater power in the institution. 
On one hand, if we consider that to access the position of Rector it is necessary to be a tenured professor of any of the Schools and in this last position, a total of 265 men have been reported compared to 120 women, the possibility of a male being elected is twice as high to that of women, especially considering cultural factors, the social networks in which women do not participate and the image of male leadership that operates on the ideal of leader of the social collective.

On the other hand, the existing gender gap in positions of individual power has a straight implication on the participation of women in managerial positions of both individual and shared power.

Thus, taking as an example to analyze the position of dean, it is seen that the requirement is also to be a tenured professor, however another relevant fact that cannot be overlooked is that the dean is the one who presides over the Directors Councils of the School and for that same position, he directly take part of the Higher University Council and the University Assembly. Considering that among the powers of the Directors Council of each School is to elect the Dean and Vice-Dean by simple majority and with a greater number of men in these organisms, the probability that a male will be elected is very high due to the factors mentioned above.

Basically, the key variable for the greater presence of women in government organisms is access to the position of tenured professor, inasmuch as this is a determining requirement to be elected as Rector, Vice-Rector, Dean and Vice-Dean.

For the most part of theorists' contributions refering female participation in power indicate that women are excluded from spaces considered masculine where relevant information is shared, which in many cases is essential for decision-making. These strategies are subtle and unconscious mechanisms that generate informal support from men each other to get to power, which at the same time intensify the male image for positions of power and discourages women to run for government positions (MORELO ALONSO; CUADRADO GUIRADO; GARCÍA AEL; RECIO SABOYA; RUEDA LAFFONT; 2009).

What can be observed in this analyzed situation is the male monopolization of managerial positions, which is related to what Herrera (2000) points out about the manipulation that institutions exert on women to carry out secondary support, opinion and management jobs considered traditional female spaces linked to care (SERAFINI GEOGHEGAN; 2018), meanwhile the majority of positions of power (which generate status, prestige, economic accumulation and personal and gender power) are held by men.

These obtained results coincide with the theory of the glass labyrinth, because although politics, nor institutional regulations deny women's access to positions of power, the unconsciously configured barriers demand greater effort and time from women to reach them ( EAGLY AND CARLI; 2007).

The findings of this research are similar to the study realized by Contrera González (2018) at the National University of Asunción (UNA) in terms of the reduced female presence in the government of the 
university, mainly in the most powerful positions such as rectorate, vice-rectorete and the deaneries. However, it differs in terms of the greater presence of women in the student representation of the UNA, a fact that does not happen in the studied university.

Likewise, the results presented confirm what was stated by Cuadrado; Molero; Navas (2003) when pointing out that in most Western societies the presence of women in managerial areas is lower, regardless of the academic training they have.

\section{CONCLUSIONS}

Finally, in the university studied, the male presence predominates in positions of shared and individual power, generating a gender gap of 1.6 at the institutional level.

Likewise, the greater female presence is located at the base of the pyramid of power, so as one ascends to the top, the number of women decreases and the male presence in positions increases.

The Tenured Professor category is, altogether with cultural factors, a key element to achieve the power of representation and election by vote, so it is essential to review the conditions of access and permanence in this position in order to allow a greater balance between genders.

There is a slight reduction in the gender gap compared to that of 2017 , this means an advance aimed at equitable democracy in the university government. However, the rate of female participation in positions of shared power constitutes a barrier of access to positions of power.

Equally, the possibility of access to positions of power by women in the short and medium terms is constrained by current conditions: participation rate, policies and norms for access, existence of informal networks to support men, organizational culture, image of male leadership, hindrances to familywork balance that lead women to resign or postpone assuming positions of greater power, and finally, the stereotyped image of gender still in force in institutions and in society.

There are invisible factors that unconsciously intervene in the construction of a male image as an ideal leader and hinder women in their professional career. These factors are based on culture and promote the reproduction of stereotyped images and roles.

This reality poses the challenge of rethinking the policies and institutional mechanisms to reduce inequalities in the medium term, in such a way as to generate conditions of equitable access to the senior management of the university government, as established by the IV Plan 2018-2024. 


\section{BIBLIOGRAPHIC REFERENCES}

Contrera González, M. (Julio- Diciembre de 2018). Las mujeres en los órganos de CONTRERA GONZÁLEZ, M. (Julio- Diciembre de 2018). Las mujeres en los órganos de gobierno de la Universidad Nacional de Asunción. ACADEMO.Revista de investigación en Ciencias Sociales y Humanidades, 5(2), 110-116. Recuperado el 18 de Mayo de 2020, de https://bit.ly/3cUQmsI

CUADRADO , I., \& MORALES, F. (2007). Algunas claves sobre el techo de cristal en las organizaciones. Revista de Psicología del trabajo y de las organizaciones, 23(2), 183-202. Recuperado el 2002 de octubre de 2017, de https://goo.gl/2v1hmC

CUADRADO, I., MOLERO, F., \& NAVAS, M. (2003). El liderazgo de hombres y mujeres: diferencias en estilos de liderazgo, relaciones entre estilos predirectores de variables de resultado organizacional. Acción Psicolñogica, 115-129.

EAGLY, A., \& CARLI, L. (2001). Throough the labyrinth. The truth about how women become leaders. Boston, Massachusetts, Estados Unidos: Harvard Business School Publising Corporation. Recuperado el 20 de Octubre de 2019

INSTITUTO TECNOLÓGICO DE COSTA RICA. (s.f.). Equality Igualdad de Género. Recuperado el 2015 de Diciembre, de http://www.equality-network.net/node/2

MINISTERIO DE LA MUJER, PARAGUAY. (20 de Diciembre de 2018). "V Plan Nacional de Igualdad 2018 - 2024 (IV PlaNI). Recuperado el 5 de Octubre de 2020, de Portal MinMujer: http://www.mujer.gov.py/index.php/noticias/se-aprobo-iv-plan-nacional-de-igualdad-2018-2024

MORELO ALONSO, F., CUADRADO GUIRADO, I., GARCÍA AEL, C., RECIO SABOYA, P., \& RUEDA LAFFONT, B. (12 de Diciembre de 2009). Mujer y liderazgo en el siglo XXI: Una aproximación psicosocial a los factores que dificultan el acceso de la mujer a los puestos de alta responsabildiad. Obtenido de Ministerio de Igualdad: www.inmujer.gob.es/areasTematicas/estudios/.../mujerLiderazgo.pd

SERAFINI GEOGHEGAN, V. (2018). Trabajo remunerado de las mujeres desde un enfoque de género. Asunción, Central, Paraguay: Centro de Análisis y Difusión de la Economía Paraguaya, CADEP. Recuperado el 5 de Octubre de 2020, de http://www.cadep.org.py/2018/01/trabajo-remunerado-de-lasmujeres-desde-un-enfoque-de-genero/

WIRTH, L. (2011). International Labour Office., \& Tripartite Meeting on Breaking through the Glass Ceiling: Women in Management (Segunda ed.). International Labour Office - Geneva. Recuperado el 29 de Setiembre de 2020, de https://www.ilo.org/public/libdoc/ilo/2001/101B09_102_engl.pdf 